\title{
marketing.
}

Članci/Papers

\section{Millennials and Gamification - A Model Proposal for Gamification Application in Tourism Destination}

Slavko Alčaković, Danijel Pavlović, Jovan Popesku

\begin{abstract}
A wide range of scientific and professional literature deals with the topic of gamification in tourism, defining it as a new trend. In this paper a model for applying the concept of gamification at the level of the tourism destination is proposed. As a basis, and an introduction to the analysis in this paper, millennials are selected as a market segment with high dynamic growth on the tourism market. The role and importance of millennials for tourism and destinations are especially reflected in their traveling habits, lifestyle and dedication to the use of new technologies in everyday life, and in particular playing games. The commitment of this tourism demand segment to gaming activities, as well as the fact that millennials will make a significant part of the tourism market in the future, points to the need to establish a link between millennials, gamification and its application which may provide multiple benefits for both tourists and tourism destinations. Those benefits are reflected in the improvement of the overall tourist experience as a fundamental product in tourism, on the one hand, and in the improvement of all tourism destination elements.
\end{abstract}

Key words: Millennials, Gamification, Tourism destination, Model
JEL: L38, M31

\section{INTRODUCTION}

Competitiveness among tourist destinations is growing increasingly. Following an increasing of international tourist arrivals, more and more tourist destinations are involved in struggle for achieving a better position in the global market. World Tourism Organization forecast show that by 2030, international tourist arrivals will grow to 1.8 billion (UNWTO, 2017, p. 3). The participation of "millennials" in total number of future tourist arrivals, as very prospective tourism segment in the fast growing tourism, is an increasingly important topic among professional and scientific community. Millennials, or also known as Generation Y, will form $50 \%$ of the global workforce until 2020 (PWC, 2011). As such, they will take a significant share in overall tourism travel in the future. Having in mind that millennials are spending more money on travel than Generation X and Baby Boomers (PWC, 2011), understanding their needs, wants, and behaviour is more then essential for future development of tourism destinations and creation of memorable tourism experience which can be considered as the fundamental tourism product (Stickdorn \& Zehrer, 2009; Popesku \& Pavlović, 2013; Pavlović, Avlijaš, \& Stanić, 2016). Millennials represent the generation "born for technology". They brought technology into the economic and cultural focus and cannot understand their life without it. When traveling they use their phones, IPads and tablets to check in, buy tickets, share comments and advices etc. In addition to that Millennials are playing video games with an average of 10000 hours a year (Shore, 2011). In this paper multiple benefits for the tourism destination are considered by focusing in the future to the needs and wants of Millennials regarding also they contribution to the new popular trend for tourism named Gamification in tourism. The question is how destination can benefit form Millennials and Gamification in the future especially using it to improve tourist experience while visiting and staying in tourism destination. In this paper we analyse Millennials role in tourism, place and importance of Gamification as an emerging trend and linking it with creating memorable tourism experience and with wide benefits to tourism destinations. 


\section{MILLENNIALS AND TRAVEL}

Millennials have higher desire to travel than any other group, and to travel abroad as much as possible (BCG, 2013), making they travel a top priority (Clark, 2017). By the end of 2020 Millennials will make $20 \%$ of international travellers (Fuggle, 2015, Mohn, 2014) with roughly of $\$ 200$ billion spent a year (Heller, 2016). In the magazine Fast Company, Dan Rush states that millennials will spend more money and will travel more than Generation X and Baby boomer generation (Rush, 2015). The reasons for situation are less married couples and less children comparing to Generation $\mathrm{X}$ and Baby Boomers. Strutner is explaining that Millennials think that it is better to travel, than to save money for retirement (Strutner, 2014). Also Millennials by travelling are getting additional skills that can translate into a competitive advantage in the workplace. (Machado, 2014). Successful tourism destination of the future will have to understand Millennials' unique travel expectations: to gain experience, recognition, and value by saving, earning, and learning while traveling (Heller, 2016).

The Topdeck Travel research shows one interesting fact: Millennials are no longer seeking a "party-animal" atmosphere when traveling, and instead want to fully experience new cultures, local cuisine (Lane, 2016). Just under half of Millennials said they would choose a destination because they want to experience a particular culture, and $78 \%$ want to learn something new while traveling and $72 \%$ would spend more money on experiences than material items (Clark, 2017). They want custom travel experiences that reinforce their individuality. Because they were so often rewarded growing up, Millennials value things that appeal to their sense of uniqueness (Heller, 2016). The technology is an important fact of their travel - 66\% Millennials would book a travel on the smartphones and $97 \%$ of millennial travellers post on social networks to share their experiences while traveling (Curelate, 2016). This generation is to become essential to the tourism and travel industry.

\section{GAMIFICATION FOR TOURISM - ESSENTIALS AND ADVANTAGES FOR TOURISM DESTINATIONS}

Millennials are seeing "real life as video game" with the "winning" as their slogan (Shore, 2011). Jane McGonigal, leading game designer, in her book, "Reality is broken: How games make us better and can change the world", shows the gaming usage data (Jenkins, 2015): 67\% of total households play video games, $97 \%$ of young adults play video games, the average number of years of one games has is $35,61 \%$ of $\mathrm{CMO}$, $\mathrm{CFO}$, CEO play video games. There is no such thing that engages one Millennial more than a video game (Jenkins, 2015) and the games come naturally to them since they learn the mechanics of gameplay since they were born (Nielson, 2013). What most important is that Millennials frequently gets the „credit“ as the generation that triggered the need for gamification (Ishn, 2016) Taking into our conclusion that Millennials will be the stronger spending force in tourism comparing to Generation X and Baby Boomers (Rush, 2015) with the unbreakable ties with technology and its affection to video games, the concept of gamifications emerges as one of the main factors for their engagement and their perception of the quality of the experience while traveling and staying in tourism destinations.

"Gamification" as a term originated in the digital media industry. The first documented use dates back to 2008 , but the term did not see widespread adoption before the second half of 2010 (Deterding, Dixon, Khaled, \& Nacke, 2011). "Gamification" is the use of game design elements in non-game contexts." (Deterding, Dixon, Khaled, \& Nacke, 2011, p. 10) or "the process of using game thinking and game mechanics to solve problems and engage users" (Helgason, 2010). It can be also defined as the use of game mechanics in several everyday activities (Wu, 2012). Zichermann and Linder describes gamification as the process in which ideas for creating games, loyalty, and behavioural economy are used to engage consumers (Zichermann \& Linder, 2013). The topic of gamification in academic literature was researched and the data showed 818 peer reviewed articles from data bases: EBSCO Host, Proquest, Web of Science, Scopus, Science Direct, ACM Digital library, AISel (Hamari, Koivisto, \& Sarsa, 2014). Gamification, combined with other emerging trends and technologies, will have a significant impact on (GE, 2012): Innovation; The design of employee performance; Globalization of higher education; Emergence of customer engagement platforms; Gamification of personal development.

Regarding the importance of Gamification in tourism, tourism destination management and marketing, Bulencer \& Egger and Xu, Buhalis \& Weber are emphasising gamification contribution to the memorable tourism experience (Bulencer \& Egger, 2015; Xu, Buhalis, \& Weber, 2017) "Gamification can enhance tourists experiences by "getting tourists immersed into a simulated travel world", which is fantasy and 
fun in nature" (Xu, Buhalis, \& Weber, 2017, p. 257). $\mathrm{Xu}$, Buhalis \& Weber, by broad overview of literature and practical applications, further point to benefits of Gamification to tourism (Xu, Buhalis, \& Weber, 2017, pp. 247-251): Raise brand awareness (new, innovative way of marketing; advergames and advertising; promoting the brand and raise brand awareness; communicate information about destination; generate visiting interests; virtual experiential marketing and deeper engagement for tourists with destination etc.); Enhance tourist experiences (fantasy, immersion and fun; aesthetic experience delivered to tourists); Engagement (customer engagement improve brand loyalty; positive attitudes towards the brand; concretion in services management; dynamic interaction etc.); Improve tourist loyalty (improve loyalty programs by adding fun and relatedness; Entertainment (bringing fun and entertainment to marketing, enhance on site experiences; fun, interactive, and engaging experiences); Employee management (training tool).

Within the framework of the conclusions of the contribution of the Gamification to tourism and tourist destination, two aspects have been highlighted. One refers to outward function (tourist experience before, after and during travellers trip to and stay in destination) and other one to inward function (familiarize the employee, and the use for staff training programs) (Xu, Buhalis, \& Weber, 2017, p. 251).

Games are mix of motivation, engagement, adaptivity, simulation, collaboration, and data collection (Shaffer, Squire, Halverson, \& Gee, 2005) and as like that they can be used for gaining tourism experience and managing and developing destination competitiveness.

\section{GAMIFICATION APPLICATION IN TOURISM}

People don't play games for the game itself, but rather for the experiences they create for them (Kontra, 2017). Regarding that using games in tourism can provide multifunctional benefits for tourists itself and give some guidelines for development of destination product. By introducing gamification into tourism, it can cause the whole tourist experience to turn into a game in a real life, through fun, learning and physical activity (Playsign, 2014). Gabe Zichermann, the author of the book "The Gamification Revolution" equals the reason why people travel with why people play games. He states that it is all about creating memories and discovering themselves (Rosenbloom,
2013). Successful tourist destinations are focused on providing extraordinary experience for tourists and guests and gamification can be recommended for creating emotional ties and reactions with tourists (Kovačević, Zečević, \& Veljković, 2014).

Think thank and Jessika Weber reported that there are different types of games when the gamification is applied in tourism (Weber, 2013):

- Location-based Augmented Realty Games. Location-based games take visitors on individual and interactive walks through the place being visited. Examples: Stockholm Sounds, Tripventure;

- Gamified tour guides: Gamified Travel Tours for Urban and Rural Environments. The visitor is exploring the city on a scavenger hunt adventure which runs on a mobile app. Examples: Foursquare, Stray Boots, America s State Park Foundation - Geochalende;

- Gaming in Theme Parks - Augmented Playful Experiences in Adventure Parks. The augmented experience is used for visitor guidelines through the park. Examples: The World Disney company theme parks (visitor guidance), The Dutch Theme Park Efteling (witch hunt);

- Gaming in Cultural Heritage - Gamified Immersive Experiences in Cultural Heritage. Cultural heritage sites increasingly use new forms of learning, drawing on the concepts of serious gaming (games with a purpose) and gamification. Example: Ghost Game Wartburg Castle, Germany;

- Gamification and Transmedia Storytelling. Uses social media platforms and other interactive networks to create a narrative and deliver a story. Example: Travel Plot Porto;

- Gamified Restaurant Experience. Uses current technology such as mobile phones to interact with digital billboards to get free food from the nearest restaurant. Example: The Pick n' Play game;

- Gamification in Hospitality. Applied in hospitality in two different ways; employer motivation and customer engagement;

- Gamified Flying Experience. The passengers can collect miles which can be points for some stages of the game. Example: KLM Meet and Seat, Virgin America Seat-to-Seat Delivery Feature;

- Experiencing Virtual Cultural Heritage. Within these virtual worlds, travellers learn about people, the cultural setting and artefacts from ancient times. Example: Virtual Romans Leicester;

- Gamified Virtual Travel Experience. Games for tourism applications are also available for those 


\section{marketing}

who want to experience the world from the secure distance of their couch, or are yet indecisive about where to go and would like to try out different travelling styles and destinations in advance. Examples: Expedia's Around the World in 100 Days, Smile Land from the Tourism Board of Thailand, Serbia Convention Bureaus „Tour de Serbia“.

Terlutter i Capella name two main groups of gamification applications (Terlutter \& Capella, 2013): advergames - real computer games, mobile games with the goal of promoting specific products, services or ideas, or tourism destination and marketing practices - platforms with the elements of game design and game like communication in the offline experience. This is not a real computer game. The flaw of gamification is that there is not a standardized model (Seaborn, 2015).

\section{A MODEL PROPOSAL}

In this paper authors try to set the stage for the main elements and pre-model conditions that all tourist destinations can use to create gamified experience of visiting tourism destination. The main model that should be used is a revised and altered model of Huang and Soman which can be applied in tourism (Huang \& Soman, 2013) (Figure 1).

When creating the gamification model for tourism, it is necessary to comply with the 5 steps:

Step 1. Understanding the target group and the context. When creating a model, it is necessary to understand the destination visitors, their characteristics, needs and wants, as well as their skills, are they coming to the destination in groups or individually. It is also necessary to understand the seasonality of business in destinations and the elements of tourist destinations: attractiveness, accessibility and destination facilities and services. "Painful points" of tourist's experiences during the trip and stay in the tourist destination are essential to determine in this phase which are at this point influenced by: motivation, skills, physical, mental and emotional factors, factor environment and the nature of the gamified experience.

Step 2. Each creator of the experience of a tourist destination should be attentive to what every tourist wants to experience. Objectives examples: The feeling that was fun; the feeling that was interesting; History of the city and cultural heritage; Architecture; that the destination is as itself beautiful, etc. These are the main ones and can be expended depending on Step 1 analysis. Three goals are essential:

1. General goal - that tourists visit the whole destination, and share everyday experiences during the stay in the destination;

2. Specific goals - e.g. That during the visit to the specific site, attractive location, tourists do 4 tests with $95 \%$ accuracy, and to share the knowledge they gained;

3. The goals related to the behaviour - for example: how long did it take for the tourists to visit and tour the destination - how many times tourists shared images on social networks.

Step 3. Create the structure of the planned experiences of tourism destination. The step where fun is generated. At this step destination management should take into account the subjectivity of the experience which is reflected in fun. Firstly it is necessary to divide the experience into the gamified levels. It is important to define the game level and weight level changes, depending on the skills acquired during the visit, and playing games. It is necessary to determine the goals that are measurable, as obstacles, constraints and aggravating circumstances (obstacles and constraints) which change depending on difficulty level. Example: Tour the local destination - stages of experience: Stage 1 - Basic knowledge of destination; Stage 2 - Walking tour through destination; Stage 3 - Find the hidden historic ornaments; Stage 4 - Find 10 places for the perfect photo moment and share; Stage 5 - Create your new route with recommendations to others (share).

FIGURE 1. The main model applied for gamified experience of visiting tourism destination

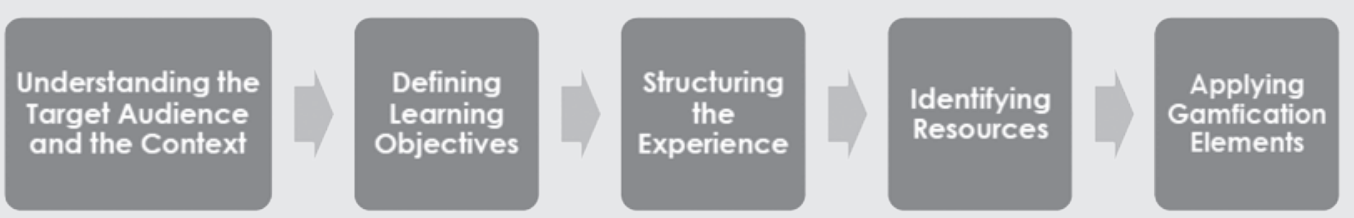

SOURCE: Adopted from Huang \& Soman (2013) 
Step 4. Identify the resources needed. After the stages are identifies, the creator of gamified experience should think about some questions: Can a tracking mechanism be applied to this specific stage? What would be the currency and what determines the accomplishment of a level? Are there clear rules that can be implemented? Does the overall system give the tourist/destination feedback? (Huang \& Soman, 2013, p. 11).The feedback is essential both for tourists and destination management - both positive and negative feedback are important, especially for tourism destination management. Game itself should provide the possibility of appealing and expressing dissatisfaction with the elements of the destination product what is an information collected by destination management.

Step 5. Using elements of gamification. Game mechanics, Game dynamics, and game aesthetics. (Kontra, 2017). Aesthetics refers to the emotion of joy and suspense, but any feeling being induced by the game could be considered to be game aesthetics (Bunchball, 2010). The positive emotions are essential for tourist and destination management should focus on them. Negative emotions are part of the feedback, used for improvement of destination experience by destination management which further lead to improvement of a destination product and competitiveness. Game mechanics could be points, levels, trophies, badges, achievements, virtual goods, leader boards, and virtual gifts e.g. the rules and rewards of the game (Bunchball, 2010). Game dynamics is represents player behaviour of game mechanics in various contexts which are combined with desires and motivations leading to those emotions in game aesthetics (Bunchball, 2010).

\section{CONCLUSION}

Gamification has become an inevitable part of marketing strategies (Zichermann \& Cunningham, 2011; Witt, Scheiner, \& Robra-Bissantz, 2011). Gamification isn't just a buzzword or a gimmick. Done correctly, it triggers real, powerful human emotions. It generates positive user experiences, increases engagement and loyalty (Brown, 2017).

Millennials as a growing market segment will make a significant part of the tourist demand in the future. To this end, the monitoring of trends by tourist destinations opens up space to adapt and focus on new market segments using information technologies and multiple benefits of gamification. Smart use of game technology can make it possible to increase the possibilities of the destination to more efficiently and effectively monitor the activities of its tourists, while providing a better ex- perience and gathering information necessary for improving the destination product and its competitiveness.

The result of such a game should be covered by positive and negative information on the tourist experience in the destination. Positive feedback is more important for tourists, in this context, since they are bringing their experience back home forwarding it to the friend and relatives. All data for each of the tourists should be stored and analysed by destination management so it could give guidelines for further development. At this point tourists are pointing to the positive and negative side of the experience for each of the elements of the destination product. Information that tourists may potentially provide to destination management relate to (possibility of completing the task and grading it in comparison to other destinations with an option of leaving the comment): Uniqueness of resources, attractions etc. compared to other destinations they have visited Information of protected and clean environment; Favourable weather and climate conditions in destination; Access to information about destination; Transport to, from and within destination; Affordable cost of services; Interaction and communication with local population; Food quality in tourist destination; Accommodation quality; Diversity of activities, entertainment and programmes. At this point destination management should decide what information are to be public (sharing, posting etc.) and what are to be used for the improvement of experience in the future.

Gamification, as a technological tool, found application at various levels of tourism in the world, both at the level of the tourist destination and at the level of the tourism industry SMEs, or some special products in tourism e.g.: "Ireland town" - National Tourism Development Authority; "Smiled Land Thailand" game - Tourism Authority Thailand (TAT); "Discover Hong Kong city" - Hong Kong Tourism Board; "REXplorer" - Regensburg; "Marriot my hotel" - Marriot Hotel Group etc. (Xu, Buhalis, \& Weber, 2017). In Serbia, the use of Gamification in tourism is not much applied as it can and should be. The analysis in this paper sets out the Serbia Convention Bureau game „Tour de Serbia“ (Kovačević, Zečević, \& Veljković, 2014). However, its widespread application in Serbia can not yet be spoken, especially at the level of the tourist destination (local, regional and national). In line with modern trends, this paper highlights the need, of developing gamification applications in Serbia in order to enable not only a better tourists experience during they travel and stay in the destination, but also a feedback to the destination management, which can be used for further development of destination product. 
1. BCG. (2013). Travelling with millennials. Retrieved from Boston Counsalting Group: https://www.bcg. com/documents/file129974.pdf

2. Brown, B. (2017). The Psychology of Gamification in 2016: Why It Works (\& How To Do It!). Retrieved from Bitcatcha: https://www.bitcatcha.com/blog/2016/ gamify-website-increase-engagement/

3. Bulencer, P., \& Egger, R. (2015). Gamification in Tourism, designing memorable experiences. Norderstedt: Bod: Books on Demand.

4. Bunchball, I. (2010). Gamification 101: An Introduction to the Use of Game Dynamics to Influence Behavior. Retrieved April 3, 2017, from Computer house house: https://www.csh.rit.edu/ ajman/ summer2012/gamification101.pdf

5. Clark, S. (2017). 4 ways millennials are changing the face of travel. Retrieved February 18, 2017, from Huffington Post: http://www.huffingtonpost.com/ sarah-clark/4-ways-millennials-are-ch_b_10503146. html

6. Curelate. (2016). Millennials travel industry. Retrieved March 25, 2017, from Curelate: https://www.curalate. com/blog/millennials-travel-industry/

7. Deterding, S., Dixon, D., Khaled, R., \& Nacke, L. (2011). From game design elements to gamefulness: defining gamification. 15th International Academic MindTrek Conference: Envisioning Future Media Environments, (pp. 9-15). Tempere, Finland.

8. Fuggle, L. (2015). 6 travel trends for 2016 that will drive the global tourism industry. Retrieved March 16, 2017, from Trekk soft: https://www.trekksoft.com/en/ blog/travel-industry-trends-2016

9. GE. (2012). Gartner's gamification predictions for 2020. Retrieved from Growth engineering: http://www.growthengineering.co.uk/future-ofgamification-gartner/

10. Hamari, J., Koivisto, J., \& Sarsa, H. (2014). Does Gamification Work? - A Literature Review of Empirical Studies on gamification. 47th Hawaii International Conference on System Sciences (pp. 3025 -3034). Hawaii, USA: IEE Computer Society.

11. Helgason, D. (2010). Trends. Retrieved march 7, 2017, from Unity Technologies Blog: https://blogs.unity3d. com/2010/01/14/2010-trends/

12. Heller, M. (2016). Millennial Expectations Are Reshaping Travel Industry. Retrieved june 2016, 13, from The gbrief: http://thegbrief.com/articles/ millennial-expectations-are-reshaping-travelindustry-602

13. Huang, H.-Y. W., \& Soman, D. (2013). A Practitioner's Guide to Gamification of education. University of Toronto, Rotman School of Management. Toronto: University of Toronto.
14. Ishn. (2016). Five Gamicication trends to watch. Retrieved from ISHN: http://www.ishn.com/ articles/103353-five-gamification-trends-to-watch

15. Jenkins, R. (2015). 5 aspects of games to leverage for increased milenial engagement and retention. Retrieved May 14, 2016, from HR Cloud: https:// blog.hrcloud.com/5aspectsofgamestoleverage forincreasedmillennialengagementretention/

16. Kontra, A. (2017). Gamification in Business. Retrieved March 30, 2017, from Kontra Agency: https://kontra. agency/gamification-in-business/

17. Kovačević, I., Zečević, B., \& Veljković, S. (2014). Gamification'concept: Theoretical framework and destination marketing management practice. Ekonomika preduzeća, 62(5-6), 315-322.

18. Lane, L. (2016, January 5). Are Millennial Travel Trends Shifting in 2016? Retrieved february 16, 2017, from Forbes: https://www.forbes.com/sites/ lealane/2016/01/15/are-millennial-travel-trendsshifting-in-2016-youll-be-surprised/\#19d0672836a8

19. Machado, A. (2014). How Millennials Are Changing Travel. Retrieved June 2016, 2016, from The Atlantic: http://www.theatlantic.com/international/ archive/2014/06/how-millennials-are-changinginternational-travel/373007/

20. Mohn, T. (2014). The Rising Wave Of Millennial Travelers. Retrieved June 13, 2016, from Forbes: http://www.forbes.com/sites/tanyamohn/2014/11/08/ the-rising-wave-of-millennial-travelers/\#62f0abfc3715

21. Nielson, B. (2013). Training and Education for Millennials through Gamification. Retrieved June 6, 2016, from Your training Edge: http://www. yourtrainingedge.com/trainingandeducation formillennialsthroughgamification/

22. Pavlović, D., Avlijaš, G., \& Stanić, N. (2016). Tourist Perception as key indicator of destination competitiveness. Teme, XL(2), 853-868.

23. Playsign. (2014). Gamification meets tourism. Retrieved June 6, 29, from Playsign: http://www. playsign.net/gamification-meets-tourism/

24. Popesku, J., \& Pavlović, D. (2013). Competitiveness of Serbia as a tourist destination, Analysis of selected key indicators. Marketing, 44(3), 199-210.

25. PWC. (2011). Reshaping the workplace. Retrieved jun 30, 2016, from https://www.pwc.com/gx/en/ managing-tomorrows-people/future-of-work/assets/ reshaping-the-workplace.pdf

26. Rosenbloom, S. (2013). Let's Play: Making Travel a Game. Retrieved june 6, 2016, from The Ney York Times: http://www.nytimes.com/2013/06/02/travel/ lets-play-making-travel-a-game.html?_r=0

27. Rush, D. (2015). How Millennials Are Redefining Business tavel. Retrieved 6 13, 2016, from Fast 
company- Business and Inovation: http://www. fastcompany.com/3053174/thefutureofwork/

28. Seaborn, K. \&. (2015). Gamification in theory and action: A survey. International Journal Of HumanComputer Studies, 7414-31.

29. Shaffer, D., Squire, K., Halverson, R., \& Gee, J. (2005). Video games and the future of learning. Phi Delta Kappan, 87(2), 105-111.

30. Shore, N. (2011). Millennials Are Playing With You. Retrieved June 20, 2016, from Harvard Business Review: https://hbr.org/2011/12/millennials-areplaying-with-y/

31. Stickdorn, M., \& Zehrer, A. (2009). Service design in tourism: Customer experience driven destination management. First Nordic Conference on Service Design and Service Innovation. DeThinking ServiceReThinking-Design 24th-26th October. Oslo, Norway.

32. Strutner, S. (2014). 29 Reasons Millennials Make The Best Travelers. Retrieved June 16, 2016, from The Huffington Post: http://www.huffingtonpost. com/2014/05/06/millennial-travel_n_5247226.html

33. Terlutter, R., \& Capella, M. L. (2013). The gamification of advertising: analysis and research directions of in-game advertising, advergames, and advertising in social network games. Journal of Advertising,, 2(2-3), 95-112.
34. UNWTO. (2017). UNWTO Tourism Highlights 2017 Edition. Madrid: UNWTO.

35. Weber, J. (2013). Gaming and Gamification in Tourism. Retrieved July 4, 2016, from Think thank: https://thinkdigital.travel/wp-content/ uploads/2014/05/Gamification-in-Tourism-BestPractice.pdf

36. Witt, M., Scheiner, C., \& Robra-Bissantz, S. (2011). Gamification of online idea competitions: Insights from an explorative case. Informatik schafft Communities, (p. 192). Berlin.

37. Wu, M. (2012). The gamification backlash + two long term business sstrategies. Retrieved march 20, 2017, from http://lithosphere.lithium.com/t5/science-ofsocial-blog/The-Gamifi cationBacklash-Two-LongTerm-Business-Strategies/ba-p/30891

38. Xu, F., Buhalis, D., \& Weber, J. (2017). Serious games and the gamification of tourism. Tourism Management, 60, 244-256.

39. Zichermann, G., \& Cunningham, C. (2011). Gamification by design: Implementing game mechanics in web and mobile apps. Sebastopol, CA: O'Reilly Media, Inc.

40. Zichermann, G., \& Linder, J. (2013). The gamification revolution: How leaders leverage game mechanics to crush the competition. McGraw Hill Professional.

Napomena: Verzija rada na srpskom jeziku prezentovana je na naučnoj konferenciji „Izazovi i problemi savremenog marketinga" održanoj na Zlatiboru od 17. do 19. novembra 2017. godine i publikovana u zborniku radova čiji je izdavač časopis Marketing. 


\section{marketing}

\section{Apstrakt:}

\section{Milenijalci i gejmifikacija - \\ Predlog modela za primenu gejmifikacije u turističkim destinacijama}

Slavko Alčaković, Danijel Pavlović, Jovan Popesku

Široka naučna i stručna literatura obrađuje temu gejmifikacije u turizmu kao novi trend. U ovom radu predložen je model za primenu koncepta gejmifikacije na nivou turističke destinacije. Kao osnova i uvod u analizu u ovom radu posmatrani su milenijalci kao tržišni segment sa visokom dinamikom rasta na turističkom tržištu. Njihova uloga i značaj za turizam i turističke destinacije posebno se ogleda u navikama pri putovanju, stilu života i posvećenosti upotrebi novih tehnologija u svakodnevnom životu, a naročito igranju igrica. Upravo, posvećenost ovog segmenta tražnje igranju igrica kao i činjenica da će milen- ijalci činiti značajan deo turističkog tržišta u budućnosti upućuje na potrebu da se u ovom radu uspostavi veza između milenijalaca, gejmifikacije i njene primene u cilju obezbeđivanja višestrukih koristi za turiste i turističke destinacije. Koristi se ogledaju u unapređenju ukupnog turističkog doživljaja kao fundamentalnog proizvoda u turizmu, s jedne strane i unapređenju svih elemenata turističke destinacije.

Ključne reči: Milenijalci, Gejmifikacija, Turistička destinacija, Model

Kontakt:

Slavko Alčaković

salcakovic@singidunum.ac.rs

Danijel Pavlović

dpavlovic@singidunum.ac.rs

Jovan Popesku

jpopesku@singidunum.ac.rs

Univerzitet Singidunum, Danijelova 32, 11000 Beograd 